\title{
The use of Tissue PatchTM to Reduce the Duration of Air Leak Following Lung Volume Reduction Surgery.
}

\author{
Alexandra Monaghan ${ }^{1 *}, V_{i j a y ~ J o s h i}{ }^{2}$, Sridhar Rathinam ${ }^{2}$ \\ From World Society of Cardiothoracic Surgeons 25th Anniversary Congress, Edinburgh \\ Edinburgh, UK. 19-22 September 2015
}

\section{Background/Introduction}

Prolonged post-operative air leak is a recognised complication in patients receiving lung volume reduction surgery (LVRS). Some patients are transferred to a portable fluttervalve bag to facilitate discharge. TissuePatchTM is a synthetic absorbable self-adhesive film which acts as an adjunct to minimise air leak.

\section{Aims/Objectives}

Our aim was to see whether the use of TissuePatchTM would reduce post-operative air leak and the subsequent need for a drain in LVRS patients.

\section{Method}

We retrospectively analysed LVRS cases over a two year period performed by a single surgeon to minimise procedural heterogeneity. Patients were divided into two groups; group 1 received Tissue PatchTM as the staple line adjunct and group 2 did not.

\section{Results}

There were 26 cases in total (one excluded due to in hospital death); group $1=12(2=$ bilateral procedures, $10=$ upper lobe procedures, median age 65 ), group $2=13$ (all unilateral, all upper lobe procedures, median age 63). The median length of stay was 15 for both groups $(\mathrm{p}=0.40)$. The median duration of air leak was 13 days for group 1 and 18 days for group $2(\mathrm{p}=0.95)$. Only $2 / 12$ (16\%) in group 1 did not have full resolution of air leak and drain removal prior to discharge and were placed on a portable flutter-valve bag compared to $5 / 13(38 \%)$ in group $2(\mathrm{p}=0.64)$.

${ }^{1}$ University of Leicester, Leicester, Leicestershire, LE1 7RH, UK

Full list of author information is available at the end of the article

\section{Discussion/Conclusion}

We have observed a reduced trend in the number of patients being discharged with persistent air leak following LVRS with the concomitant use of Tissue PatchTM. A larger study is indicated which may demonstrate significant results.

\section{Authors' details}

'University of Leicester, Leicester, Leicestershire, LE1 7RH, UK. ²Department of Thoracic Surgery, Glenfield Hospital, University Hospitals of Leicester,

Leicester, Leicestershire, UK.

Published: 16 December 2015

doi:10.1186/1749-8090-10-S1-A13

Cite this article as: Monaghan et al:: The use of Tissue PatchTM to Reduce the Duration of Air Leak Following Lung Volume Reduction Surgery.. Journal of Cardiothoracic Surgery 2015 10(Suppl 1):A13.

\section{Submit your next manuscript to BioMed Central and take full advantage of: \\ - Convenient online submission \\ - Thorough peer review \\ - No space constraints or color figure charges \\ - Immediate publication on acceptance \\ - Inclusion in PubMed, CAS, Scopus and Google Scholar \\ - Research which is freely available for redistribution \\ Submit your manuscript at www.biomedcentral.com/submit}

